\title{
Moradores de cortiço, capitães da areia e cobradores urbanos: personagens excluídos da construção da ordem nacional
}

Eliana Kuster ${ }^{1}$

Boa-vida olhou a cidade, fez um gesto com a mão. Era como um adeus. Boa-vida era malandro e ninguém ama a cidade como os malandros...

Jorge Amado, Capitães da areia

O historiador Paul Veyne (2003), em seu ensaio "Foucault revoluciona a história", aborda a prática da gladiatura no Império Romano, tentando analisar em qual momento histórico esse hábito já consolidado naquele cotidiano passou a ser posto em questão. Apresentada como uma prática que provocava "atração e repulsa", a violenta luta entre homens em uma arena foi considerada inaceitável em algumas sociedades. Não em Roma, porém. Veyne se questiona sobre os motivos da aceitação dessa prática naquele preciso contexto e, indo além, sobre o momento histórico no qual a luta entre gladiadores passa a ser considerada uma barbárie entre os romanos e, como tal, indesejada. O que o interessa, porém, não é exatamente a figura do gladiador ou a prática das lutas. Ele se debruça sobre esse tema para constatar quais as razões para essa mudança ter ocorrido em um hábito já consolidado culturalmente. Segundo ele:

$\mathrm{Na}$ grande maioria da população, a gladiatura provocava, assim como o carrasco, sentimentos ambivalentes, atração e prudente repulsa; de um lado havia o gosto em ver sofrer, o fascínio da morte, o prazer de ver cadáveres, e, de outro, a angústia de ver que no próprio seio da paz pública, assassínios legais são cometidos e que não são assassínios de inimigos nem de criminosos: o estado de sociedade não mais defende contra a lei da selva. Em muitas civilizações, esse medo político prevaleceu sobre a atração: é a ele que se deve a suspensão dos sacrifícios humanos. Ao contrário, em Roma, a atração levou a melhor e foi assim que se instalou essa instituição dos gladiadores que é única na história universal.

Mas, o mais espantoso não é essa inesperada falta de humanitarismo, mas sim, que essa inocência na atrocidade era legítima, e até

\footnotetext{
${ }^{1}$ Doutora em planejamento urbano, professora efetiva do Instituto Federal do Espírito Santo (IFES), Vitória, ES, Brasil, e professora convidada da École de Hautes Études en Sciences Sociales (EHESS), Paris, Île-de-France, França. E-mail: elianakuster@gmail.com
} 
legal, e até mesmo organizada pelos poderes públicos; o soberano, garantia do estado de sociedade contra o estado de natureza, era, ele próprio, o organizador desses assassinatos lúdicos em plena paz pública e, nos anfiteatros, os arbitrava e os presidia (Veyne, 2003, p. 152-153).

Assim sendo, em face desse panorama tão consolidado, o historiador avança um passo rumo ao momento em que essas lutas passam a ser consideradas indesejáveis, e se questiona sobre qual foi a mudança, qual pequeno peso foi depositado naquela balança que estava tão bem equilibrada entre o horror e a fascinação, e a fez pender para o primeiro.

Veyne afasta as explicações fáceis que atribuiriam a suspensão dos combates aos valores cristãos ou humanitários, e busca levantar outras questões. Defende, a partir da reconstrução histórica, do garimpo de pequenos fatos, a necessidade de se afastar a cortina do senso comum e progredir rumo ao verdadeiro motivo dos acontecimentos. Segundo ele, é necessário perscrutar o problema, virá-lo ao avesso como a uma roupa. Somente assim "os falsos problemas morrem por asfixia e o problema verdadeiro aparece" (Veyne, 2003, p. 155).

A partir desse raciocínio, e utilizando as contribuições de Foucault no que diz respeito à necessária desnaturalização dos fenômenos para que, a partir daí, possa ser construída uma genealogia, o autor vai nos apresentar outro panorama, e, a partir dele, atribuir o cessamento das lutas a uma modificação substancial no papel do soberano. Construindo uma longa análise sobre a mudança na figura do imperador no momento em que o Senado é desfeito em Roma, Veyne apresenta a mudança crucial: o governante deixa de lado o desempenho de seu papel como "guia de um rebanho' - rebanho esse que seria a população sob seu governo -, e passa a assumir um papel de "pai' daquela população. E as atitudes que seriam tomadas por um governante "guia', não são as mesmas assumidas por um governante "pai". Neste, a necessidade de proteger e cuidar moralmente de seus "filhos' é maior do que, no outro, o seu "rebanho". Veyne chega, portanto, à conclusão que nos é central para o desenvolvimento do raciocínio que se segue:

Em vez de acreditar que existe uma coisa chamada "os governantes" relativamente à qual os governados se comportam, consideremos que os "governados" podem ser tratados segundo práticas tão diferentes, de acordo com as épocas, que os ditos governados não têm senão o nome em comum (Veyne, 2003, p. 154).

Daí que, a esse governante "pai", já não pareça adequado manter as lutas entre os gladiadores, considerando que seus "filhos" devam ser protegidos da excessiva barbárie patrocinada pelo Estado. 
Embora tratando de temas radicalmente diferentes, é a partir desse raciocínio que se desenvolve o texto que se segue: buscando perscrutar alguns conceitos e a sua necessária contextualização histórica para a construção de um panorama sobre algumas questões referentes à história do planejamento no Brasil.

Somando as contribuições de autores como Nabil Bonduki, Jaime Benchimol, Luiz Cesar de Queiroz Ribeiro, Adauto Cardoso e Robert Pechman, em suas considerações sobre a formação das cidades brasileiras e qual o papel que as habitações populares desempenharam nesse contexto, foi construído o embasamento teórico para o desenvolvimento do texto. $\mathrm{O}$ impasse que o problema da moradia poderia trazer na incorporação de uma ordem urbana é tratado por esses autores em períodos históricos diferentes do país. Ao panorama traçado por eles, fomos buscar um contraponto em três obras da literatura brasileira que abordam períodos diversos atravessados pelo país. São elas: O cortiço, de Aluísio Azevedo, escrito em 1890; Capitães da areia, de Jorge Amado, de $1937 ;{ }^{2}$ e o conto O cobrador, do livro de mesmo nome, de Rubem Fonseca, publicado em 1979.

A intenção é, ao unir textos de embasamento teórico - sobre o planejamento urbano e a questão da moradia - aos provenientes do campo da ficção, construir um panorama que mostre a evolução e as modificações do conceito de ordem na cidade brasileira e, consequentemente, a mudança em relação aos que devem ser enquadrados por ela, sendo inseridos ou excluídos do panorama pretendido em cada período da história do país, bem como das soluções relativas à questão habitacional então adotadas.

Voltando a Veyne e suas análises sobre os diversos papéis desempenhados por essa figura cristalizada sob a alcunha de "governante", poderíamos parafraseá-lo e questionar: o que representou o conceito de "ordem" em momentos diferentes da história e do planejamento brasileiros? Certamente não o mesmo conteúdo, o mesmo objetivo, as mesmas questões. Para inferirmos essas mudanças, basta nos determos sobre os discursos que versam sobre a construção da nação brasileira e tentarmos analisar que pontos estão sendo privilegiados em cada época, bem como quais são os aspectos considerados indesejáveis - porque "desordenadores" - a esse Brasil que se deseja construir.

Especificamente um personagem da cidade nos interessa: o vagabun-

\footnotetext{
${ }^{2} \mathrm{O}$ artigo foi escrito utilizando como base uma edição do livro de Jorge Amado intitulada Capitães de areia. Constatamos, porém, ao longo do processo de revisão editorial, que a versão original do livro intitula-se Capitães da areia. Foram modificadas as referências ao longo do texto, mas a citação bibliográfica final permanece como no livro consultado.
} 
do, ou malandro, duas formas que diferentes tempos históricos construíram para nomear essa figura que se encontra à margem do mundo do trabalho. É interessante, ao abordarmos esse panorama, a constatação de como essa figura urbana, que inicialmente destacava-se de uma certa "ordem" pretendida para a cidade e para a vida dos citadinos, após algum tempo passa a estar destacado em relação à lei: de "fora da ordem" à "fora da lei", a figura do homem que mora na cidade e não tem uma ocupação é, ao nosso ver, uma das possibilidades por meio das quais é possível acompanhar as mudanças acontecidas nas cidades, no planejamento e, talvez, na violência no Brasil ao longo do século XX.

Embora as obras ficcionais selecionadas para a abordagem aqui tratem de cidades diversas - Rio de Janeiro e Salvador -, o que se infere a partir da sua leitura, e mais, a partir de sua articulação em certa linha temporal e epistemológica, vale, em maior ou menor grau, para todo o país. Essas obras foram selecionadas mantendo-se atenção aos critérios enunciados por Antônio Candido ao tratar do que é denominado por ele como "redução estrutural', ou seja, "o processo por cujo intermédio a realidade do mundo e do ser se torna, na narrativa ficcional, componente de uma estrutura literária" (Candido, 1993, p. 9). Assim, ainda seguindo orientações desse autor, foram buscadas obras dentre aquelas nas quais

natureza, sociedade e ser parecem presentes em cada página, tanto assim que o leitor tem a impressão de estar em contato com realidades vitais, de estar aprendendo, participando, aceitando ou negando, como se estivesse envolvido nos problemas que eles suscitam. Essa dimensão é com certeza a mais importante da literatura do ponto de vista do leitor, sendo o resultado mais tangível do trabalho de escrever (Candido, 1993, p. 9).

Unindo, portanto, a construção histórica - baseada em fatos e pesquisas documentais - e a representação - realizada pelos escritores ficcionais -, é que tentaremos delinear um panorama que espelha o fato de que a ideia de nação, no Brasil, foi sendo construída sob um viés fortemente pautado pela noção de manutenção de uma ordem urbana - condição esta fundamental ao engendramento de uma ordem nacional, em um país que se urbanizava rapidamente -, na qual vários vão ser os personagens indesejados. Empurrados para as franjas da cidade e da sociedade, aqueles que foram sistematicamente excluídos - e que aqui encontram sua metonímia nos "moradores de cortiço" e "capitães da areia" -, contemporaneamente, não estão mais dispostos a aceitar passivamente essa exclusão. Transformam-se assim, para nos referirmos ao termo utilizado por Rubem Fonseca, nos "cobradores" de nossa sociedade atual. 


\section{O cortiço}

\section{Aluísio Azevedo, 1890}

E naquela terra encharcada e fumegante, naquela umidade quente e lodosa, começou a minhocar, a esfervilhar, a crescer, um mundo, uma coisa viva, uma geração, que parecia brotar espontânea, ali mesmo, daquele lameiro, $e$ multiplicar-se como larvas no esterco.

Aluízio de Azevedo, O cortiço

O romance $O$ cortiço se passa no Brasil do segundo império. Retrata o processo de construção e ampliação de um cortiço em Botafogo, no Rio de Janeiro, e as relações construídas entre seus moradores e a vizinhança, bem como as imbricações entre as diversas camadas sociais que compunham a cidade.

No trecho que abre esta seção, retirado do livro de Azevedo, já se torna claro o paralelo do cortiço - daquele amontoado de gente "esfervilhante" - com algo do mundo natural, que se multiplica e cresce espontaneamente. É justamente esse aspecto "fúngico" dos vários cortiços e habitações coletivas espalhados pelo tecido urbano que passa a incomodar alguns setores da cidade do Rio, especialmente a partir da primeira grande epidemia de febre amarela, ocorrida entre 1849 e 1850. Sabemos, a partir do relato do médico alemão Bertoldo Lallement, que a doença era particularmente rigorosa com aqueles de origem europeia, enquanto os negros escravos ou os de raça "mista" sofriam menos (Lallement apud Benchimol, 1990, p. 14). Ou seja, a parcela da população sobre a qual se derramava o maior dano da febre amarela era a elite branca, o que explica em boa parte a preocupação que vai originar as medidas de saneamento urbano que começam a ser implementadas tendo como justificativa o combate às epidemias. As providências tomadas passaram por um viés fortemente pautado pela medicina social, que procurava prevenir as possíveis epidemias, cuidando de suas causas ambientais. Essa postura requereu intervenções rígidas, que cuidassem de "transformar a desordem em ordem, através de um trabalho contínuo e planificado de vigilância e controle da vida social" (Machado apud Benchimol, 1990, p. 115, grifo nosso).

A concentração de muitas pessoas em um espaço reduzido era um dos inimigos contra os quais se batia a medicina social. Especificamente no caso do Rio de Janeiro esse aspecto era visto como um grande problema, 
já que as condições climáticas e geográficas da cidade, ao favorecerem a retenção de calor e umidade, eram consideradas críticas, não favorecendo a limpeza dos miasmas que, acreditava-se, originavam as doenças. Assim foi que, um pouco depois dessa série de epidemias, foi decretada a proibição da construção de casas coletivas de habitação no centro da cidade, então a sua área nobre, o que causou um aumento desse tipo de habitação na chamada "Zona Sul".

A cidade já havia sofrido intervenções espaciais anteriormente, embora de ordem diversa. A chegada da Missão Francesa, em 1816, havia sido a responsável pela implantação de uma série de iniciativas modernizadoras no Rio, que tiveram influência estética em outras cidades. Os franceses haviam trazido uma concepção de cultura, arte e arquitetura provenientes de uma Europa que já se encontrava no seio da Revolução Industrial, espelhando, portanto, uma realidade completamente diferente da brasileira. Por esse motivo, não foram elaborados planos que se ocupassem da cidade como um todo, tendo sido feitas apenas algumas intervenções pontuais de embelezamento. É ainda Benchimol que analisa, referindo-se ao arquiteto francês Grandjean de Montigny:

Grandjean não concebeu um plano de conjunto para a remodelação da cidade. Sua perspectiva consistiu, fundamentalmente, em implantar, no coração da fervilhante e barroca cidade dos trópicos, amplos espaços e imponentes estruturas em estilo neoclássico, onde o trono europeu e, depois, o poder imperial brasileiro pudessem se exibir, com toda magnificência. Tratava-se de inserir na trama da cidade as inscrições do poder que, antes, estavam na metrópole (Benchimol, 1990, p. 36).

A cidade, que ao longo do século XIX havia crescido e se ampliado desordenadamente, em especial com o portentoso aumento na quantidade de habitantes desde a instalação da corte portuguesa, verá refletido no romance de Azevedo o retrato acabado dessa falta de um planejamento abrangente. A sua população, na primeira metade do século, havia triplicado, e começava a se espalhar para outras regiões periféricas ao centro. Além disso, as classes sociais se diversificavam e distanciavam, embora ainda estivessem misturadas no tecido urbano.

Escrito em 1890, O cortiço - romance inspirado em L'assommoir, de Émile Zola (1877) - vai retratar o quadro resultante desse crescimento desordenado, e captar exatamente o momento em que a cidade encontra-se cingida por duas questões: de um lado, a vontade de modernizar-se nos moldes europeus, e, de outro, uma herança colonial que engendrou uma sociedade pautada pelo trabalho escravo. Isso vai gerar cidades nas quais há, ainda, uma forte necessidade do trabalho braçal 
realizado por operários sem qualificação - operários estes aos quais a cidade precisava abrigar.

Essas questões relacionadas à reorganização do espaço e à carência habitacional das classes mais baixas apresentaram-se mais cedo no Rio que em algumas outras cidades brasileiras, mas estas também passaram por processo semelhante. Ao descrever como se sucedeu esse processo em São Paulo, Bonduki (1998) também vai reafirmar o empenho da elite em conferir à cidade um panorama europeizado, o que transformava a presença das habitações populares na região central em um problema. Na apresentação dos quatro tipos de moradias populares existentes em São Paulo ao final do século XIX, o autor descreve exatamente o tipo de estrutura encontrado no romance de Azevedo, o "cortiço-pátio":

O cortiço ocupa comumente uma área no interior do quarteirão: quase sempre um quintal e um prédio onde há estabelecida uma venda ou tasca qualquer. Um portão lateral dá entrada por estreito e comprido corredor para um pátio com 3 a 4 metros de largo nos casos mais favorecidos. Para esse pátio, ou área livre, se abrem as portas e janelas das pequenas casinhas enfileiradas, com o mesmo aspecto, a mesma construção, as mesmas divisões internas e a mesma capacidade (Bonduki, 1998, p. 25).

Ressalvadas as peculiaridades, essa é a distribuição espacial do ambiente no qual se passam os fatos narrados por Aluísio Azevedo: originado ao redor da venda de seu proprietário, o português João Romão, o cortiço se espalha, composto de pequenas casas amontoadas e insalubres.

É possível proceder a uma leitura do romance utilizando o viés da contradição apontado por vários autores que se debruçam sobre esse período: a mistura do passado colonial e da inclinação à modernização. Havia, por um lado, a vontade de se europeizar, de se transformar realmente em uma capital, e, por outro, os entraves para tal, causados principalmente pelos valores arcaicos nos quais se baseava a sociedade brasileira e pela junção de forças e valores tão distintos quanto os que constituíram o Brasil.

No romance abordado, temos o embate entre duas forças: o "malandro" nacional e o "trabalhador" europeu, nas figuras dos personagens Firmo e Jerônimo. Na luta pelo amor de uma terceira personagem, Rita Baiana, há mais que simplesmente uma disputa amorosa: há uma disputa entre povos e valores distintos. O português, aparentemente, ganha o coração da moça. Mas, para tal, precisou deixar a sua família, sua identidade, seus valores, seus hábitos se perderem em troca de outros, que acabaram por transformá-lo no estereótipo apresentado como sendo o do brasileiro: indolente, preguiçoso, malandro. 
É possível detectarmos, em várias situações ao longo do livro, o embate "ordem" versus "espontaneidade". Ou, em uma conceituação mais abrangente, "cultura" versus "natureza". Talvez o melhor exemplo seja o cenário no qual os acontecimentos se sucedem: a pedreira em Botafogo. Esta vai, no desenrolar do livro, sendo dilapidada para a exploração de seu material e, ao mesmo tempo, para dar lugar a mais casas no cortiço, transformando-se, assim, na metonímia de várias das situações narradas. A pedreira é, então, absolutamente simbólica de uma situação na qual se impõe uma nova "ordem" à natureza, sendo essa ordem imposta de forma desordenada até a entrada em cena da figura do operário português especializado, que vai organizar a extração da pedra e aumentar a produtividade do material e dos empregados. Aquele operário, Jerônimo, seria o retrato acabado do trabalhador que se desejava para a construção da nação, servindo, com seus valores e posturas revestidos de seriedade e correção, de exemplo para os demais.

Mais tarde, porém, esse mesmo trabalhador vai ser rendido em sua força e organização de trabalho pela força do desejo por uma mulher, que lhe mina o empenho no emprego e o faz tornar-se indolente e malandro como os outros moradores do cortiço. E, como qualquer outro brasileiro, o autor nos diz claramente ao descrever as transformações em Jerônimo:

O português abrasileirou-se para sempre; fez-se preguiçoso, amigo das extravagâncias e dos abusos, luxurioso e ciumento; fora-se-lhe de vez o espírito da economia e da ordem; perdeu a esperança de enriquecer, e deu-se todo, todo inteiro, à felicidade de possuir a mulata e ser possuído só por ela, só ela e mais ninguém (Azevedo, 1995, p. 175, grifo nosso).

Nesse sentido, temos o desejo apresentado como um forte opositor ao estado de ordem pretendido, ameaça representada especialmente pela figura da mulher, conforme advoga Ferreira, ao defender a necessidade da construção de residências unifamiliares para os trabalhadores:

Observando o cortejo dos malefícios da habitação precária para a moradia familiar, vamos encontrar o grande inimigo do pudor e do recato feminino. Convém que a vida da mulher derive numa atmosfera de discrição e de respeito que só se obtém na habitação individual. No cortiço e em outras moradias semelhantes, desde o amanhecer até o cessar tardio do movimento de inquilinos, está a mulher à vista de todos, sujeita à promiscuidade, desde o tanque comum até as demais instalações. Essa freqüentação diária com indivíduos de outro sexo, estranhos à família, vai aos poucos despudorando a mulher pela impossibilidade de deixar esta de ser vista a todo instante e com qualquer traje. Entretanto, o recato feminino é a barreira natural de que Deus dotou para preservá-la 
da malícia, da sensualidade e dos atentados da ordem moral (Ferreira apud Bonduki, 1998, p. 86).

Vemos aqui uma preocupação que - para além do cuidado com a figura feminina, claramente expresso - dirige-se ao perigo que esta representaria ao estado de ordem necessário para se formar uma nação que deveria pautar-se por valores referentes ao trabalho. A mulher, nesse quadro, deveria ser mantida longe dos olhares masculinos, conservando seu "pudor" e "recato", de forma a não se constituir em uma tentação que desviasse os ânimos masculinos do trabalho.

Embora escrito em 1942, esse posicionamento de Ferreira e as preocupações demonstradas por ele estão bem antevistos nos acontecimentos que se passam no romance de Azevedo, onde as mulheres são apresentadas, senão como personagens meramente devassas, como propícias a tal. Nesse sentido, temos o personagem de Piedade, a portuguesa mulher de Jerônimo, que, ao ser abandonada por este, começa a beber e deixa de trabalhar, tornando-se símbolo dessa transição dos valores ordeiros e tradicionais mantidos dentro de uma família nuclear, rumo à devassidão dos costumes à qual se está sujeito em uma moradia coletiva. $\mathrm{O}$ mesmo acontece com Pombinha, jovem casta e ingênua, com casamento já acertado com Costa, mas que, exposta àquela mistura confusa de homens, mulheres e seus dramas pessoais, pouco a pouco desenvolve uma nova percepção de mundo:

Num só lance de vista, como quem apanha uma esfera entre as pontas de um compasso, mediu com as antenas de sua perspicácia mulheril toda aquela esterqueira, onde ela, depois de se arrastar por muito tempo como larva, um belo dia acordou borboleta à luz do sol. E sentiu diante dos olhos aquela massa informe de machos e fêmeas, a comichar, a fremir concupiscente, sufocando-se uns aos outro [...], a moça pressentiu bem claro que nunca daria de si ao marido que ia ter uma companheira amiga, leal e dedicada; pressentiu que nunca o respeitaria sinceramente como a um ser superior por quem damos a vida (Azevedo, 1995, p. 129-130).

A exposição à moradia coletiva e o contato muito próximo com todos os dramas ali contidos cobra seu preço da personagem. Seu casamento não resiste, e sua vida muda radicalmente a partir do momento no qual se torna consciente de seu poder de fêmea sobre os homens.

O romance espelha, assim, uma preocupação real: a degradação dos hábitos sociais através da vivência muito próxima - diversas questões, portanto, que são consideradas nos discursos que pregam a eliminação das moradias coletivas. Ao abordar as justificativas oficiais apresentadas para a eliminação dessas moradias, Bonduki, em poucas palavras, resume 
esse panorama no qual se apresentam problemas que misturam questões de ordem religiosas, morais e familiares:

Obrigada a viver na habitação coletiva, a mulher estaria condenada a desejar e a se deixar desejar, a atentar contra as normas sexuais cristãs, a romper o isolamento do lar e sofrer o contágio de um meio propício ao pecado. O homem, por sua vez, seria afetado por riscos tão ou até mais graves para a ordem social: a criminalidade e a vagabundagem (Bonduki, 1998, p. 86, grifo nosso).

Trata-se de interessante colocação que põe lado a lado a criminalidade e a vagabundagem, como problemas irmãos que seriam decorrentes do convívio coletivo, de certo "determinismo" do ambiente. Qual será a conclusão que podemos inferir daqui? Não há a possibilidade de construção dessa ordem desejada, dessa cidade desejada, a não ser por meio da subjugação dos anseios que surgem do coletivo? Essa construção de uma nação que tenha como força motriz o trabalho sempre esbarrará nas questões locais, em entraves que são constitutivos das próprias pessoas, ou nas impossibilidades conferidas pelo ambiente?

Temos, no romance $O$ cortiço, uma exposição dessas questões, por meio de alguns personagens que são apresentados como estando fora da ordem desejada por essa nova sociedade: são os malandros, os que não têm trabalho fixo e vivem de jogos, das lutas de capoeira, ou fazendo pequenos bicos. Embora "fora da ordem" pretendida, ou seja, fora do padrão desejado para a construção da nação brasileira, não estão ainda fora da lei. Isso não significa que não cometam crimes: eles acontecem, por motivos passionais, por brigas, ciúmes. Mas esses "vagabundos", que não têm trabalho fixo, e viram-se um dia de cada vez, não têm no crime uma forma de vida. Ou seja, ainda não representam um perigo para a sociedade e para o estado de ordem. Além disso, convivem no mesmo espaço de personagens que são caros a esse perfil desejado, bastando lembrar que no mesmo cortiço reside, dividindo o espaço com esses malandros, Alexandre, "um mulato de quarenta anos, soldado de polícia, pernóstico, de grande bigode preto, queixo sempre escanhoado e um luxo de calças sempre engomadas e botões limpos na farda, quando estava de serviço" (Azevedo, 1995, p. 37-38). Sobre o mesmo personagem é apresentado um curioso paradoxo:

Alexandre, em casa, à hora de descanso, nos seus chinelos e na sua camisa desabotoada, era muito chão com os companheiros de estalagem, conversava, ria e brincava, mas envergando o uniforme, encerando o bigode e empunhando sua chibata, com o que tinha o costume de fustigar as calças de brim, ninguém mais lhe via os dentes e então a todos falava teso e por cima do ombro (Azevedo, 1995, p. 38). 
O uniforme de policial reveste Alexandre de "ordem". Sem ele, torna-se "muito chão", ou seja, igual a todos os outros com os quais convive no cortiço. Esse é o preciso momento da transição, no qual os diversos personagens da cidade - e da "ordem" pretendida para a vida coletiva - ainda convivem entre si. $\mathrm{O}$ romance aborda exatamente esse ponto no qual essa situação começará a se alterar, como veremos em seu desenrolar, que já mostra uma certa segmentação da cidade.

Ao final do romance, vemos o cortiço ser incorporado à cidade, modernizando-se e ampliando-se. O dono do cortiço, o português João Romão, ao mesmo tempo em que incorpora melhorias em seu empreendimento, faz o mesmo com sua vida pessoal. A escrava Bertoleza, com quem havia se amasiado, dá lugar à mocinha portuguesa de boa família. Da mesma maneira como Bertoleza foi excluída da "ordem" pessoal pretendida pelo português, as melhorias no cortiço - e na cidade que o rodeia - também geram a sua parcela de exclusão, na figura de moradores que migram para outro local de moradia coletiva um pouco mais distante, o "Cama-de-gato".

Os moradores do cortiço de João Romão se renovaram, e já não eram "gente sem gravata e sem meias" (Azevedo, 1995, p. 181). O próprio local mudou de nome, de "Estalagem São Romão" transforma-se em "Avenida São Romão", em uma tentativa de emular-se com a cidade:

A feroz engrenagem daquela máquina terrível, que nunca parava, ia já lançando os dentes a uma nova camada social que, pouco a pouco, se deixaria arrastar inteira lá para dentro. Começavam vir estudantes pobres [...], vieram contínuos de repartições públicas, caixeiros de botequim, artistas de teatro, condutores de bondes e vendedores de bilhetes de loteria (Azevedo, 1995, p. 182, grifo nosso).

Os novos habitantes do cortiço, portanto, passam a ser descritos em termos de suas profissões: acabou o lugar para a malandragem. $\mathrm{O}$ trabalho é o meio de inserção nessa cidade que, em breve, passará pelas intervenções que lhe renovarão os espaços e segmentarão a continuidade do tecido urbano. O quadro traçado por Azevedo em seu romance cristaliza esse panorama da transição, antevendo o preciso momento em que a mudança se inicia, e delineando assim os personagens que serão, brevemente, enquadrados em uma outra ordem urbana.

\section{Capitães da areia Jorge Amado, 1937}

Vestidos de farrapos, sujos, semi-esfomeados, agressivos, soltando palavrões e fumando pontas de cigarro, eram, em verdade, os donos da 
cidade, os que a conheciam totalmente, os que totalmente a amavam, os seus poetas...

Jorge Amado, Capitães da areia

A história de Jorge Amado narra as aventuras de um grupo de meninos pelas ruas de Salvador na década de 1930. Mostra o cotidiano de pequenos delitos que acontecem em uma cidade que já tem seu território fragmentado segundo suas camadas sociais e os rumos diversos tomados por cada um dos meninos que formam o grupo denominado "Capitães da areia". Desligados das respectivas famílias, esses meninos encontram uns nos outros a possibilidade de coexistência em grupo, protegendo-se mutuamente e apoiando-se na tarefa de sobreviver das ruas.

Os capitães da areia passeavam livremente pelas ruas e conheciam Salvador como a palma de sua mão. Na verdade, eram, segundo Jorge Amado, "os que a conheciam totalmente, os que totalmente a amavam" (Amado, 1998, p. 21).

A cidade brasileira - seja ela o Rio de Janeiro, São Paulo ou mesmo Salvador, onde se passa a história de Amado - já começou a se partir. Os bairros se diferenciam por classes, e ela - a cidade - só se dá a conhecer parcialmente, não mais em sua totalidade. Se ninguém mais a conhece totalmente, ninguém mais a ama totalmente. Seria o caso de perguntarmo-nos de ainda há uma totalidade possível. A resposta é dada pelos "capitães": os únicos que amam Salvador inteiramente, posto que os únicos que a conhecem inteiramente. Indiferentes à fragmentação da cidade, à separação de seus bairros em classes sociais, os meninos a percorrem inteira, da cidade alta à baixa. Das docas às avenidas. Do trapiche no qual vivem às mansões que invadem para roubar. Cometem pequenos furtos como meio de vida. Representam, para a nossa argumentação, uma etapa à frente daqueles malandros da obra anterior: aqui, os personagens que estavam apenas "fora da ordem" no romance de Azevedo, já começam a estar "fora da lei". Representam uma geração na qual a contravenção já começa a ser seu modo de vida.

Desde as primeiras décadas do século $X X$, grandes projetos de transformação urbanística mudaram radicalmente a face de cidades como Rio e São Paulo. Essas mudanças acarretaram, em maior ou menor grau, modificações em outras cidades do país. Ao final dos anos 1930, boa parte das capitais brasileiras tinha sofrido a sua própria reforma "haussmanizadora". A maior parte delas caracterizou-se pelo viés da exclusão. Nas palavras de Bonduki:

As intervenções urbanísticas na área central de São Paulo nos anos 10 foram uma outra forma do poder público enfrentar a questão das 
habitações insalubres, à moda de Haussmann e Pereira Passos: expulsando seus moradores e demolindo os cortiços, para afastá-los do centro (Bonduki, 1998, p. 37).

Essas intervenções urbanas tinham como principal objetivo, portanto, a criação de uma nova imagem para a cidade, buscando nos modelos europeus o espelho no qual se mirar, e conferindo às elites urbanas os signos de distinção espacial desejados por estas. Segundo Ribeiro e Cardoso,

A modernização se torna então o princípio organizador das intervenções. Essa modernização terá, todavia, como sua principal característica a não-universalidade. De fato, as novas elites buscam desesperadamente afastar de suas vistas - e das vistas do estrangeiro - o populacho inculto, desprovido de maneiras civilizadas, mestiço. As reformas urbanas criam uma cidade "para inglês ver" (Ribeiro e Cardoso, 1996, p. 59).

As reformas modernizadoras criaram, portanto, uma classe ainda mais marginalizada, agora espacialmente. Misturando justificativas oriundas do higienismo com o temor do contato dessa classe de marginalizados com ideologias políticas de esquerda, os agentes dessas modificações vão defender a erradicação das moradias coletivas utilizando argumentos como: "São as casas imundas o berço do vício e do crime. [...] O socialismo destruidor e pernicioso para o progresso de uma nação encontra, nesses centros de grandes cidades, uma atmosfera favorável para o seu engrandecimento" (Veiga apud Bonduki, 1998, p. 34). Até a década de 1940, esse tipo de discurso irá persistir como justificativa às remodelações e à erradicação das habitações coletivas nas regiões centrais das cidades brasileiras.

Vivia-se, na verdade, um paradoxo, já que, apesar de indesejada sob muitos aspectos, essa parcela da população marginalizada, se transformada em força de trabalho, continuava a ser necessária para que a economia capitalista se firmasse dentro dos padrões desejados no país. Decorre daí que "os cortiços e as casas coletivas eram, portanto, essenciais para a reprodução da força de trabalho a baixos custos e, enquanto tal, não podiam ser reprimidos e demolidos na escala prevista pela lei e desejada pelos higienistas" (Bonduki, 1998, p. 39).

A partir dos anos 1930, durante o governo de Getúlio Vargas, há um deslocamento na forma como a pobreza era vista até então: de inevitável e útil - já que viria daí a mão de obra para o crescimento do Brasil - ela passa a ser encarada como um entrave à construção de uma nação moderna, já que faltariam a essa parcela da população os requisitos mínimos para constituir-se como o povo sobre o qual firmar-se um país. Segue daí o raciocínio de que o combate a essa pobreza deva ser realizado pelo Esta- 
do, por meio de "uma política de valorização do trabalho como forma de ascensão social e obrigação da cidadania" (Ribeiro e Cardoso, 1996, p. 60).

Uma das formas de promoção desse combate à pobreza e valorização do trabalho eram os programas de moradia popular. A questão habitacional, que já vinha sendo colocada como problema para o país, passa a ser vista como um assunto que requer atenção com urgência, deixando a questão restrita do sanitarismo em segundo plano. O pressuposto era de que, resolvendo o problema habitacional dentro dos padrões de higiene desejados, a primeira questão estaria automaticamente sanada. Segundo Ribeiro e Cardoso, "partia-se do princípio que o trabalhador era revoltado e preguiçoso, pelas más condições de vida. A promoção da casa própria era também uma forma de promover o apoio à família" (Ribeiro e Cardoso, 1996, p. 61).

A habitação social foi tratada pelo governo em dois planos: como essencial para a reprodução da força de trabalho que visava à industrialização, e como aspecto que contribuía à "formação ideológica, política e moral do trabalhador, e, portanto, decisiva na criação do "homem novo" e do trabalhador padrão que o regime queria forjar, como sua principal base de sustentação política" (Bonduki, 1998, p. 73). Tratava-se, portanto, de utilizar os meios de acesso à moradia como instrumento de racionalização da vida e do cotidiano do trabalhador, ao mesmo tempo em que era preservada a estabilidade dos valores familiares, ao se conferir um lugar a essa família. Em um artigo de 1943, “O homem e a habitação", Arruda Câmara defende:

O alojamento barato e confortável afasta o operário da taberna e cria maiores possibilidades à família, embora o salário continue limitado. A boa casa proporciona ao operário condições necessárias à saúde física e psíquica e, sem dúvida alguma, não deverá representar um negócio de que se esperem grandes lucros, mas um dever social a realizar (Câmara apud Ribeiro e Cardoso, 1996, p. 60, grifo nosso).

É importante mencionar que, apesar de se falar amplamente em programas de "habitação popular", o déficit habitacional não estava apenas nas classes ditas populares, atingindo também a classe média, o que aumentou o interesse do governo em tratar da questão. Além disso, criar um programa que tivesse por objetivo atender a essa necessidade social vinha ao encontro da necessidade urgente do país em industrializar-se e de - visando atingir esse fim mais rapidamente - baratear o custo da mão de obra. A questão da moradia também se insere aí, já que, ao deixar de pagar aluguel indefinidamente e diminuir os gastos com a sua habitação, o trabalhador pode ter o seu salário reduzido. $\mathrm{O}$ último beneficiado acaba por ser também o empresário. 
Por fim, há o interesse - menos palpável, porém imprescindível - na formação de uma "nação" - ainda que a partir da reunião de diversas culturas provenientes de nacionalidades diferentes, mas que se acredite pertencente a um conjunto com características em comum. É necessário, portanto, que se promova a atualização de um imaginário que confira uma identidade em comum a esse povo, que deve, a partir daí, passar a assemelhar-se em suas necessidades e anseios.

Um aspecto que não deve ser desprezado diz respeito ao "apaziguamento" dessa mesma força de trabalho, satisfeita em suas necessidades básicas, e, além disso, totalmente inserida nos valores inerentes ao sistema capitalista, já que passara a ser proprietária e não mais locatária. Ao assumir uma dívida tão vultosa quanto a da compra de uma residência, o trabalhador assume também o modo de vida que decorre da necessidade de arcar com essa despesa, inserindo-se plenamente no sistema de produção de uma sociedade capitalista. Tal encadeamento de fatos estaria totalmente de acordo com o interesse do governo getulista. Bonduki resume:

A questão da moradia assumiu papel fundamental no discurso e nas realizações do Estado Novo, como símbolo da valorização do trabalhador e comprovação de que a política de amparo aos brasileiros estava dando resultados efetivos. No centro dessa concepção estava a ideia de que o trabalho dignifica e gera frutos, os quais compensariam décadas de sacrifícios (Bonduki, 1998, p. 83).

O acesso à casa própria tornara-se, portanto, equivalente ao pensamento de ascensão por meio do trabalho, e apenas o "trabalhador" oficializado e sindicalizado teria alcance a tal bem, tendo aí o incentivo para manter-se dentro dos planos traçados pelo governo para a industrialização do país. Nesse raciocínio, aquele cidadão que não tem um emprego fixo, o nosso "malandro", não possui nenhuma possibilidade de acesso a uma melhor condição de moradia. Como resultado disso, torna-se cada vez mais excluído, empurrado cada vez mais para fora desse imaginário de nação que se deseja construir.

Poderíamos pensar nessa geração como sendo, metaforicamente, a dos "pais" dos capitães da areia de Jorge Amado. Excluídos os pais, excluídos os filhos, que vêm de famílias desfeitas ou vitimadas pela fome, e passam a rolar pela cidade de Salvador cometendo contravenções como forma de sobrevivência, e sentindo crescer dentro de si a revolta contra a cidade que os despreza e exclui, explicitada em pensamentos como o de um de seus personagens, o "Sem-Pernas": "Confusamente desejava ter uma bomba (como daquelas de certa história que o Professor contara) que arrasasse toda a cidade, que levasse todos pelos ares. Assim ficaria alegre" (Ama- 
do, 1998, p. 31). É exatamente esse sentimento difuso de revolta que vai, décadas depois, gerar um personagem com o "cobrador", que nos será apresentado mais tarde por Rubem Fonseca.

Os "capitães" sentem um vazio inexplicável, o vazio do não pertencimento, uma angústia de não caber em lugar nenhum, que tentam mascarar de formas diferentes:

Todos procuravam um carinho, qualquer coisa fora daquela vida: o Professor naqueles livros que lia a noite toda, o Gato na cama de uma mulher da vida que lhe dava dinheiro, Pirulito na oração que o transfigurava, Barandão e Almiro no amor na areia do cais. O Sem-Pernas sentia que uma angústia o tomava e que era impossível dormir. Se dormisse viriam os maus sonhos da cadeia. Queria que aparecesse alguém a quem ele pudesse torturar com dichotes. Queria uma briga. Pensou em ir acender um fósforo na perna de um que dormisse. Mas quando olhou da porta do trapiche, sentiu somente pena e uma vontade doida de fugir. E saiu correndo pelo areal, correndo sem fito, fugindo de sua angústia (Amado, 1998, p. 39, grifo nosso).

Representantes de uma classe excluída, indesejada na construção dessa cidade que procura asseptizar os seus espaços e os seus cidadãos, os meninos de Salvador - e os milhares de brasileiros que se assemelham a eles - sentem a angústia da sua própria volatilidade na cidade. Indesejados, negados, ignorados, precisam extravasar essa amargura que não sabem bem de onde vem. Nesse sentido é bastante representativa a passagem acima: Sem-pernas, um dos "capitães", precisa dar vazão à sua desesperança de alguma forma. Como só conheceu a violência, é ela que primeiro lhe ocorre como forma de "fugir da sua angústia".

Senhores apenas das areias das docas, os meninos, ao final do livro, desfazem seu grupo, tornando-se - como já se antevia no título do romance dispersos como a areia que lhes conferiu o nome. Porém, mesmo dispersos, mantém traços em comum, sendo o principal deles a revolta: com a impessoalidade da cidade e com a exclusão, com os maus-tratos a que foram submetidos, com a pobreza que lhes corroeu a infância. Nesse sentido, podemos apresentar a perspectiva de um dos muitos "capitães": Volta Seca. É através dele que podemos perceber, ao final do livro, as sequelas daquela sistemática exclusão a que foi submetido. Ao voltar para o sertão de onde saíra, Volta Seca reflete sobre a sua experiência no período em que viveu em Salvador: "Muita coisa aprendeu na cidade, entre os Capitães da Areia. Aprendeu que não era só no sertão que os homens ricos eram ruins para os pobres. $\mathrm{Na}$ cidade, também. Aprendeu que as crianças pobres são desgraçadas em toda parte, que os ricos perseguem e mandam em toda parte. Sorriu por vezes, mas nunca deixou de odiar" (Amado, 1998, p. 233, grifo nosso). 
Volta Seca é a antevisão do personagem que ilustra nosso próximo momento, no conto de Rubem Fonseca: o cobrador. A revolta que cozinha lentamente dentro do menino maltratado, e que gera esse sorriso permeado de ódio, é a mesma revolta que vai mover o personagem de Fonseca para cobrar o que a cidade lhe deve, como veremos na parte que se segue.

\section{"O cobrador"}

\section{Rubem Fonseca, 1979}

Digo, dentro da minha cabeça, e às vezes para fora, está todo mundo me devendo!...

Rubem Fonseca, "O cobrador"

O conto põe em cena um personagem anônimo em estado de indignação com a sociedade que o cerca, o que o faz insurgir-se contra as regras sociais vigentes e recusar-se a fazer parte desse jogo social. Para expressar tal recusa, esse que se intitula "o cobrador", utiliza-se amplamente de comportamentos violentos, que buscam devolver-lhe algo que, nas suas palavras, a sociedade está lhe "devendo".

Podemos, à primeira vista, achar que Rubem Fonseca escreve simplesmente sobre a violência. A escrita do contista, porém, extrapola esse aspecto, rumo a outro fenômeno: a perversão. Esse termo, originado do latim perversio, designa comportamentos humanos que comprometem normas morais, sociais e sexuais estabelecidas em uma determinada sociedade. E é exatamente esse aspecto que Fonseca explora no conto "O cobrador". Ali vemos um personagem que, cansado de esforçar-se - em vão - para alcançar uma inserção na vida social da cidade, resolve penetrá-la à força. Passa a se designar "o cobrador" e assume comportamentos com os quais busca - por meio da violência - arrombar as portas da sociedade que, sistemática e historicamente, lhe virou a face. O personagem obriga essa sociedade a lhe ver, a lhe conferir existência, a partir de seus atos violentos. O que o cobrador faz é um estupro social.

Estamos no final da década de 1970. A exclusão anunciada desde o século XIX, com as primeiras reformas urbanas, e reforçada com as medidas governamentais de acesso à casa própria nos anos 1930 e 1940 já se completou, gerando suas perigosas consequências sociais. $O$ foco do pensamento sobre as intervenções no espaço urbano muda. Segundo Ribeiro, "o objetivismo tecnocrático agora predomina na formulação da questão urbana, a serviço do nacional-desenvolvimentismo. O projeto da constituição da nação desloca-se para o eixo econômico" (Ribeiro e Cardoso, 1996, p. 65). 
As cidades brasileiras estão inchadas, constituindo-se, na acepção de Ferraz, em "monstros urbanos". Segundo esse autor, há uma dinâmica perversa implicada nesse crescimento: "Monstros urbanos já surgiram, outros estão na iminência de surgir, e todos acabarão, certamente, devorando a maior parcela do seu próprio trabalho, tal o montante exigido para a sua sustentação" (Ferraz apud Ribeiro e Cardoso, 1996, p. 66).

O deslocamento apontado por Ribeiro rumo a uma nação que se constitui a partir de um viés econômico contribui à construção do perfil de um personagem considerado a quintessência da contemporaneidade: $o$ homem hipermoderno. Este se caracteriza pela perda dos referenciais que, tempos antes, mobilizaram a sociedade coletivamente, pautando-se, portanto, por um descolamento de qualquer causa ou ideologia. Seus atos originam-se do total individualismo. Segundo Carvalho, o grande fator mobilizador desse novo homem seria o consumo:

Alçado à condição de instrumento anestesiador, excitante, sedutor, exclusivista, segregador e ostentável, o consumo traduz-se como prática com valores que, não por ironia, ajustam-se à corrente hipermoderna e adequam-se ao exercício solitário que o indivíduo está fadado a executar (Carvalho, 2006, p. 7, grifos nossos).

É Zygmunt Bauman quem reforça esse argumento de uma prática que traduz-se no individualismo contemporâneo, ao definir uma das principais formas de inserir-se nessa realidade que se pretende "pós-moderna": o indivíduo tem que se mostrar sensível aos incessantes apelos do consumo, "capaz de ser seduzido pela infinita possibilidade e constante renovação promovida pelo mercado consumidor, de se regozijar com a sorte de vestir e de despir identidades" (Bauman, 1998, p. 23). Aqueles que, por qualquer motivo, não podem fazê-lo, são mantidos de fora da vida social, como o nosso personagem.

Nesse sentido, o conto de Fonseca parece antever esse indivíduo que, impossibilitado de consumir e, portanto, não inserido no exercício fundamental que caracteriza o pertencimento à sociedade, exerce solitariamente sua "cobrança" pela cidade. Pressionado pelos apelos da cidade, que lhe promete mulheres, carros, festas, que se mostram inalcançáveis, ele se cansa de esperar pelos restos que o mundo capitalista lhe atira. Resolve, então, tomar à força o que lhe foi prometido. Mas prometido por quem? É o próprio personagem que nos responde, expressando e alimentando seu ódio:

Tão me devendo colégio, namorada, aparelho de som, respeito, sanduíche de mortadela no botequim da rua Vieira Fazenda, sorvete, bola de futebol. Fico na frente da televisão para aumentar o meu ódio. Quando minha cólera está diminuindo e eu perco a vontade de cobrar o que me devem eu sento na frente da televisão e em 
pouco tempo meu ódio volta (Fonseca, 1979, p. 168).

Ao misturar na lista do que lhe devem itens como "respeito" e "bola de futebol", ele nos mostra que a questão que o atormenta não é puramente econômica. Tem uma dimensão muito maior. Segundo Hannah Arendt (1999), a cidade, a sociedade, o mundo, é muito mais do que a urgência dos interesses privados, do que a carência de bens materiais. E assim também é com o que mobiliza o nosso personagem. Tenha ou não consciência disso, o personagem de Fonseca está encenando uma luta pela cidade, ou melhor dizendo, pelo direito de existir na cidade, de pertencer a ela. Sabemos pela leitura de Kant feita por Luiz Antônio Baptista que "o homem de lugar nenhum é um angustiado criminoso em potencial" (Baptista, 1999, p. 99), ou seja, no momento em que se perde o sentido de pertencimento a um grupo, onde não há mais o reconhecimento de ser parte de um todo, perdem-se também as razões para se obedecer às regras de convivência coletiva. É nesse encadeamento de ideias que se insere a perigosa anomia do "cobrador".

Esta análise, embora à primeira vista pareça se aplicar apenas ao personagem central do conto como representante de uma classe que foi excluída - social e economicamente - da cidade, se tomada sob um ponto de vista mais amplo, vale para os demais sujeitos urbanos e sua crescente polarização. De um lado, temos o "cobrador", representante de uma classe que vai sendo empurrada para fora de certos espaços da cidade, para a qual são deixados os restos do espaço urbano. Do outro, temos quem se exclui, uma elite que abandona as ruas e se enclausura atrás de vidros de segurança, carros blindados e espaços protegidos por câmeras de vigilância. Nem o personagem de Fonseca nem os componentes desse grupo que se abstrai da cidade se veem como pertencentes a esse coletivo urbano. Nenhum deles têm sentido de "comunidade", de aspecto em comum, com a cidade. Assim, no momento em que passamos a ter no espaço urbano uma polarização entre esses grupos que já deixaram de possuir a noção de pertencimento a um mesmo conjunto, a cidade deixa de ser o lugar do encontro e da construção de relações. O acirramento desse embate, portanto, é totalmente previsível.

Georg Simmel, no ensaio intitulado "A metrópole e a vida mental", defende que uma das principais características da metrópole é a constituição de uma ligação forte entre a economia monetária e o domínio do intelecto. Segundo o autor, os citadinos

partilham uma atitude que vê como prosaico o lidar com homens e coisas; e, nesta atitude, uma justiça formal freqüentemente se combina com uma dureza desprovida de consideração. A pessoa intelectualmente sofisticada é indiferente à individualidade genuína, 
porque dela resultam relacionamentos e reações que não podem ser exauridos com operações lógicas (Simmel, 1973, p. 13).

Ou seja, o dinheiro reduz tudo a "quanto?". As individualidades e subjetividades são deixadas de lado e substituídas por um número, indiferente. Apenas a realização objetiva, mensurável, é de interesse. Deriva daí uma forma de pensar de alguns grupos urbanos que privilegia o cálculo e a quantificação. As relações interpessoais passam a se caracterizar pelo prosaicismo. Segundo Robert Pechman, "com sua mentalidade que privilegia as coisas e negligencia as pessoas, esses grupos têm da cidade a percepção de uma arena de competições, grande feira, templo do consumo" (Pechman, 2004, p. 3). E cabe aqui reforçar que a lógica que move o consumo é a da individualização. Ainda de acordo com esse autor,

Constata-se, com isso, um desencantamento da idéia de cidade e a concomitante desconstrução da noção de social e de sociedade e, conseqüentemente, da noção de política e mundo comum, com desdobramentos na própria concepção de cidadania. [...] Quando a cidade é esvaziada de seus sentidos, ela perde o seu poder de urbanidade e se torna incapaz de ser referência, incapaz de doar significado à identidade dos seus, facilitando a proliferação da violência e da incivilidade (Pechman, 2004, p. 3, grifo nosso).

Essa cidade que já apresenta uma mudança no seu sentido - ou mesmo um esvaziamento em seu sentido, como advoga o autor, é o espaço que vai gestar o sujeito da hipermodernidade. Quem analisa esse indivíduo hipermoderno em todas as suas dimensões é o sociólogo Gilles Lipovetsky, que afirma:

Cumpre-se um ritual de entorpecimento individual que se alicerça no consumo desenfreado e destemido, já que, em um gesto cínico e premeditado, o indivíduo legitimou este caráter de desordem organizada como o habitual para o seu caminhar na esteira da hipermodernidade, atribuindo à atividade consumista a função de construção de sua própria identidade: nas sociedades em que não existem mais grandes ideologias políticas, um certo número de indivíduos tende a querer afirmar a sua identidade por meio do próprio consumo. [...] Imbuído do seu esplendor solitário, o sujeito hipermoderno pode tender a um individualismo responsável ou irresponsável. Seu raio de ações articula-se justamente no que se refere a área de atuação do outro indivíduo. Compreende, enfim, o florescimento de uma consciência individual que tangencie o outro em respeito ao seu campo de ação, abrangência e valores cultivados, pois essa cultura individualista cria um terreno mais permissivo à ultrapassagem das barreiras morais e tende a relativizar, banalizar e desculpabilizar certas fraudes (Lipovetsky, 2004 , p. 53, grifos nossos). 
Ao final do conto "O cobrador", vemos o personagem, que nos havia sido apresentado como um solitário, agora com uma namorada, a "Ana palindrômica", como ele a chama. Acompanhado por Ana, moça pertencente a uma classe social elevada, o cobrador planeja uma volta à sociedade. Visa cobrar tudo o que lhe é devido, agora de forma mais "eficiente". Cercados por armas, planejam um grande massacre, a ser realizado no período do Natal e complementado por um "manifesto" pautado pelo discurso que pretende dar voz à exclusão.

A esse ponto, não é possível nos furtarmos a analisar o nome da companheira do "cobrador", que ele intitula como "palindrômica", ou seja, aquilo que possui a mesma grafia e sonoridade se lido de trás para frente ou vice-versa. É de se imaginar o que poderia ser esse gosto do personagem pelo palíndromo, por aquilo cujo som volta para o lugar de onde saiu - talvez uma volta que, metaforicamente, o cobrador deseje para si mesmo? Um retorno para a cidade, para a sociabilidade, agora nos seus próprios moldes, a partir do seu próprio conceito de social? Utilizando-se talvez de novas regras, reconstruir uma sociedade outra, vislumbrando um devir que ainda tenta apostar na vida em conjunto? Não sabemos, não podemos afirmar ao certo. Isso apenas pode ser levemente inferido por alguns "paradigmas indiciários", como nos diria Ginzburg (1988). O que podemos afirmar com certeza é que o personagem não desistiu de se fazer ver pela sociedade, ainda que essa seja uma visão forçada.

Vemos, portanto, o personagem junto a Ana. Ele agora engendra o seu próprio método, a sua própria ordem, e, a partir dessa nova ordem, busca a sua reinserção no social. À força.

Leio para Ana o que escrevi, nosso manifesto de Natal, para os jornais. Nada de sair matando a esmo, sem objetivo definido. Eu não sabia o que queria, não buscava um resultado prático, meu ódio estava sendo desperdiçado. Eu estava certo nos meus impulsos, meu erro era não saber quem era o inimigo e por que era inimigo. Agora eu sei, Ana me ensinou. E o meu exemplo deve ser seguido por outros, muitos outros, só assim mudaremos o mundo. É a síntese do nosso manifesto.

Ponho as armas numa mala. Ana atira tão bem quanto eu, só não sabe manejar o facão, mas essa arma agora é obsoleta. Damos até logo à Dona Clotilde. Botamos a mala no carro. Vamos ao Baile de Natal. Não faltará cerveja, nem perus. Nem sangue. Fecha-se um ciclo da minha vida e abre-se outro (Fonseca, 1979, p. 174, grifos nossos).

Ao cobrador, portanto, não interessa o consenso que tem por preço a exclusão. Esse personagem é a ponta relativamente atual de um longo 
processo, proveniente de muitas gerações que ao longo da história brasileira tiveram sistematicamente as portas fechadas às possibilidades de sua participação na construção da vida social, sendo aproveitados somente em seu aspecto utilitário, como mão de obra fundamental ao desenvolvimento do país, mas não ao seu engendramento enquanto nação.

Dos moradores de cortiço, dos malandros e meninos de rua, daqueles que por qualquer razão não se adequam às regras de inserção no social, podemos afirmar: a constituição da experiência urbana brasileira fez-se ao largo de tais personagens - fosse moldando-os forçadamente nos formatos desejados, fosse simplesmente ignorando-os -, em seu afã por "ordem" e "progresso". A exclusão, que foi paulatinamente perpetrada durante a maior parte do processo de formação da nação, contemporaneamente apresenta a sua conta. Esta nos chega sob a forma de violência, intolerância, perda dos laços de identificação entre os que dividem o espaço das cidades. Todos estes elementos acabam por promover o aumento na desordem urbana que tanto se tentou combater.

O que conseguimos vislumbrar a partir do panorama delineado pelas obras de ficção analisadas aqui é um percurso no qual a busca por uma "possibilidade de nação", através da construção de certa ordem, nos exibe, agora, as suas consequências. Estas remontam a todo o processo de constituição urbana do Brasil, colocando em xeque toda a estruturação desse processo e exigindo a sua reavaliação crítica. Talvez seja essa a conta a ser duramente exigida pelos atuais "cobradores" urbanos.

\section{Referências}

AMADO, Jorge (1998). Capitães de areia. São Paulo: Record.

ARENDT, Hannah (1999). A condição humana. Rio de Janeiro: Forense Universitária. AZEVEDO, Aluísio (1995). O cortiço. São Paulo: Ática.

BAPTISTA, Luís Antônio (1999). Cidade dos sábios: reflexões sobre a dinâmica social nas grandes cidades. São Paulo: Summus.

BAUMAN, Zygmunt (1998). O mal-estar da pós-modernidade. Rio de Janeiro: Jorge Zahar. BENCHIMOL, Jaime (1990). Pereira Passos, um Haussmann tropical. Rio de Janeiro: Secretaria Municipal de Cultura, Turismo e Esportes.

BONDUKI, Nabil (1988). Origens da habitação social no Brasil. São Paulo: Estação Liberdade; Fapesp.

CANDIDO, Antônio (1993). O discurso e a cidade. São Paulo: Duas cidades.

CARVALHO, Breno da Silva (2006). Do objeto cultural: o consumo. In: ENCONTRO DE ESTUDOS MULTIDISCIPLINARES EM CULTURA -ENECULT, 2., Salvador, maio. FONSECA, Rubem (1979). O cobrador. Rio de Janeiro: Nova Fronteira.

GINZBURG, Carlo (1988). Sinais: raízes de um paradigma indiciário. In: Mitos, emblemas e sinais: morfologia e história. São Paulo: Companhia das Letras. 
LIPOVETSKY, Gilles (2004). Metamorfoses da cultura liberal: ética, mídia e empresa. Porto Alegre: Sulina.

PECHMAN, Robert (2004). Entre a cidade e a cidadela: representações da urbanidade e da violência no Rio de Janeiro. Rio de Janeiro. (Projeto de pesquisa) Mimeo.

RIBEIRO, Luiz Cesar de Queiroz; CARDOSO, Adauto Lucio (1996). Da cidade à nação: gênese e evolução do urbanismo no Brasil. In: RIBEIRO, Luiz Cesar de Queiroz; PECHMAN, Robert (Orgs.). Cidade, povo e nação: gênese do urbanismo moderno. Rio de Janeiro: Civilização Brasileira.

SIMMEL, Georg (1973). A metrópole e a vida mental. In: VELHO, Otávio Guilherme (Org.). O fenômeno urbano. Rio de Janeiro: Zahar.

VEYNE, Paul (2003). Foucault revoluciona a história. In: Como se escreve a história. Brasília: Editora UnB.

Recebido em setembro de 2012.

Aprovado em abril de 2013.

\section{resumo/abstract}

\section{Moradores de cortiço, capitães da areia e cobradores urbanos: personagens excluídos da construção da ordem nacional}

\section{Eliana Kuster}

O artigo traça um panorama da questão urbana no Brasil sob o ponto de vista da construção de uma ordem nacional que reverta, no plano concreto, para a organização deste espaço urbano e de seus dilemas referentes às questões da moradia. No plano imaginário, tenta-se investigar o engendramento de um ideário do que seja a nação e de quais são os personagens desejados para a composição dessa ordem que se constitua como um fator de afirmação identitária nacional. Nesse sentido, busca-se auxílio na literatura brasileira, em seu delineamento de personagens que poderiam fazer frente a esse chamado de constituição da ordem constitutiva da nação. São, portanto, utilizados como contraponto aos autores que tratam a questão sob o enfoque histórico e social, algumas obras da literatura ficcional: O cortiço, de Aluízio Azevedo (1890), Capitães da areia, de Jorge Amado (1937) e o conto "O cobrador", de Rubem Fonseca (1979). Esses trabalhos de ficção permitem, em momentos históricos específicos, verificar como foi tratada a questão da exclusão social no país, e de como tivemos, paulatinamente, um aumento na parcela daqueles considerados indesejáveis à construção de um ordenamento do espaço urbano e da nação.

Palavras chave: cidade, literatura, representações sociais, ordem. 


\section{Slum residents, captains of the sand and urban collectors: characters excluded on construction of a national order}

\section{Eliana Kuster}

This essay provides an overview of urban issues in Brazil from the point of view of the construction of a national order that accrues for the organization of urban space and their dilemmas concerning the issues of dwellings. We tried to investigate the construction of an ideal of nation and which are the desired features for the composition of this national order, that is constituted as a factor of Brazilian identity. We looked support in the Brazilian literature, used in dialogue with scholars who are dealing with the question under historical and social focuses, through works such as $O$ cortiço, by Aluízio Azevedo (1890), Capitães da areia, by Jorge Amado (1937), and the shot story "O cobrador", by Rubem Fonseca (1979). These fiction works allow us, in specific historical moments, to verify how the matter of social exclusion in the country was handled, and as we had, gradually, an increase of those considered undesirable in the share of the construction of an urban order and of the idea of a nation.

Keywords: city, literature, social representations, order. 